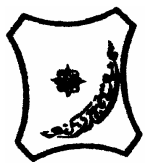

Bayero Journal of Pure and Applied Sciences, 4(2): 103 - 108

Received: July, 2011

Accepted: September, 2011

ISSN $2006-6996$

\title{
TRACE ELEMENTS AS INDICATORS OF QUALITY OF DRINKING WATER IN OFFA METROPOLIS, KWARA STATE, NIGERIA
}

\author{
*Jimoh, W. L. O. and Sholadoye, Q. 0. \\ Department of Pure and Industrial Chemistry, Bayero University Kano, P. M. B. 3011, Nigeria. \\ *Correspondence author
}

\begin{abstract}
This study involved the determination of trace elements in drinking water in Offa Metropolis. Drinking water samples were collected from tap, well, borehole, stream and sachet water and analysed for $\mathrm{Cr}, \mathrm{Co}, \mathrm{Cu}, \mathrm{Fe}, \mathrm{Mg}$ and $\mathrm{Mn}$ using Atomic Absorption Spectrophotometer. The results obtained show the concentration ranges of the metals in the samples as follows: $\mathrm{Cr}(0.01$ $0.27) \mathrm{mgL}^{-1}, \mathrm{Co}(0.000-0.018) \mathrm{mgL}^{-1}, \mathrm{Cu}(0.001-0.023) \mathrm{mgL}^{-1}, \mathrm{Fe}(0.025-0.13) \mathrm{mgL}^{-1}, \mathrm{Mg}(0.007$ - 0.082) $\mathrm{mgL}^{-1}$ and $\mathrm{Mn}(0.002-0.009) \mathrm{mgL}^{-1}$. In conclusion these concentrations are within the permissible limit of the WHO drinking water quality guidelines except chromium with twenty-one samples above the WHO threshold limit and four samples within the limit.
\end{abstract}

Keywords: Offa metropolis, Trace elements, Water quality, Kwara State, Drinking water.

\section{INTRODUCTION}

Good drinking water quality is essential for the well being of all people. Contaminated water has serious implication on the health and economic status of the population. Trace elements are among the water contaminants which find their way into water supplies as a result of inadequate treatment, disposal of wastes and industrial discharges (Singh and Mosely, 2003). Water contaminated with sewage is estimated to kill about two million children every year (Bamishaiye et al., 2011). Even in the absence of anthropogenic source, there is tendency for natural levels of metals and other chemicals to be harmful to human health (Anawara et al., 2002). This was observed recently in Zamfara State, Northern Nigeria where about 163 people lost their lives between March and June, 2010 as a result of lead poison in drinking water (Wikipedia, 2010).

Utilization of the minerals by the body is jeopardized by the presence of toxic elements such as lead, cadmium, mercury and aluminum. Fortunately, elements in the diet can also protect against toxic elements. Zinc, calcium and vitamin C protects against cadmium (Aswathanarayana, 1994). The principal objective of the present study is to investigate the input and distribution of trace elements and examine the pollution levels and quality of drinking water in Offa metropolis with respect to the most important heavy metals. Lots of the application of the solid phase extraction for metal determination in natural water samples including drinking waters has been presented by researchers (Quinaia et al., 2001; Salonia et al., 1991, Ferrarello et al., 2001).

Over - exposure to water - soluble cobalt salts (and thus the cobalt II ion) has been shown to cause damage to testicular tissue in male rats and mice. At the highest oral doses studied, fertility in male mice was significantly reduced (measured as the percentage of fertilized ova). A threshold level was also found for the adverse effects on fertility in male mice (Anderson et al., 1985; Pedigo et al., 1988).

Although minerals comprise only a fraction of total body weight, they are crucial for many body functions including transporting oxygen, normalizing the nervous system and simulating growth, maintenance and repair of tissues and bones (Dara 2006). Metals in our water supply may occur naturally or may be the result of contamination. Naturally occurring metals are dissolved in water when it comes into contact with rock or soil material. Other sources of metal contamination are corrosion of pipes and leakages from waste disposal sites (Skeat 1969). For the determination of trace elements various methods have been used, including Inductively Coupled Plasma Mass Spectrometry (ICP - MS), Electro thermal Atomic Absorption Spectrometry, and Hydride Generation Atomic Fluorescence Spectroscopy (Samuel et al., 2004).

This study was conducted with the view to determine concentrations of chromium, cobalt, copper, iron, magnesium and manganese in drinking water samples obtained from Offa metropolis in Kwara state and compared with WHO (2004) threshold limits.

\section{MATERIALS AND METHODS}

\section{Reagents and Glassware}

Analytical grade reagents and distilled water were used throughout the study. The apparatus and glassware were washed with detergent and thoroughly rinsed with distilled water. Samples were evaporated to dryness and the residues were digested with $0.25 \mathrm{moldm}^{-3} \mathrm{HNO}_{3}$ acid for Atomic Absorption Spectrophotometer (model no. vac 210) analysis of trace metals

\section{Study Area}

Offa Local Government is a town located in central Nigeria on latitude $4.62^{\circ}-4.74^{\circ} \mathrm{N}$ and longitude $8.11^{\circ}$ $8.22^{\circ} \mathrm{E}$. Offa is $100 \%$ bordered by Oyun Local Government with savanna vegetation. The main occupation in the town is farming. 
The town has a population of 114000 (Mustapha 2008). Twenty five different water samples were collected in twenty five sampling sites and coded as follows: Idi-Ogun borehole (A), Igbo-Oro borehole (B), Popo borehole (C), Temitope borehole (D), Olalomi borehole $(E)$, Ogidiri borehole $(F)$, Oyun borehole (G), Idi-Ogun sachet water $(\mathrm{H})$, Kemla sachet water (I), Oyun sachet water (J), Pennywise sachet water $(\mathrm{K})$, Yauz sachet water $(\mathrm{L})$, Oyun stream water $(\mathrm{M})$, Gogo stream water $(\mathrm{N})$, Oyun tap water (O) Idi-Ogun tap water $(\mathrm{P})$, Popo tap water (Q), Arometa well water $(R)$, Ogidiri well water $(S)$, Popo well water $(T)$, Igbo-Oro well water $(U)$, Sawmill well water $(\mathrm{V})$, Oyun well water $(\mathrm{W})$, Idi-Ogun well water (X) Ojomu well water (Y)

\section{Sample Collection and Preparation}

Water samples were obtained from Offa Local Government and part of Ijagbo town in Oyun Local Government area, all in Kwara State. Twenty five different water samples were collected from the well, borehole, tap, stream and sachet water using a plastic polythene container.

\section{Sampling of Well and Borehole Water}

Samples were collected from well and borehole after the well has been pumped to ensure that the samples represent the ground water source. Grab samples were collected three times daily at interval of 3 hours and were mixed to obtain composite samples which was then collected in a five litres polythene plastic container. For borehole, water was allowed to run for few minutes before collection so as to obtain a uniform flow rate (Soylak et al., 2002).

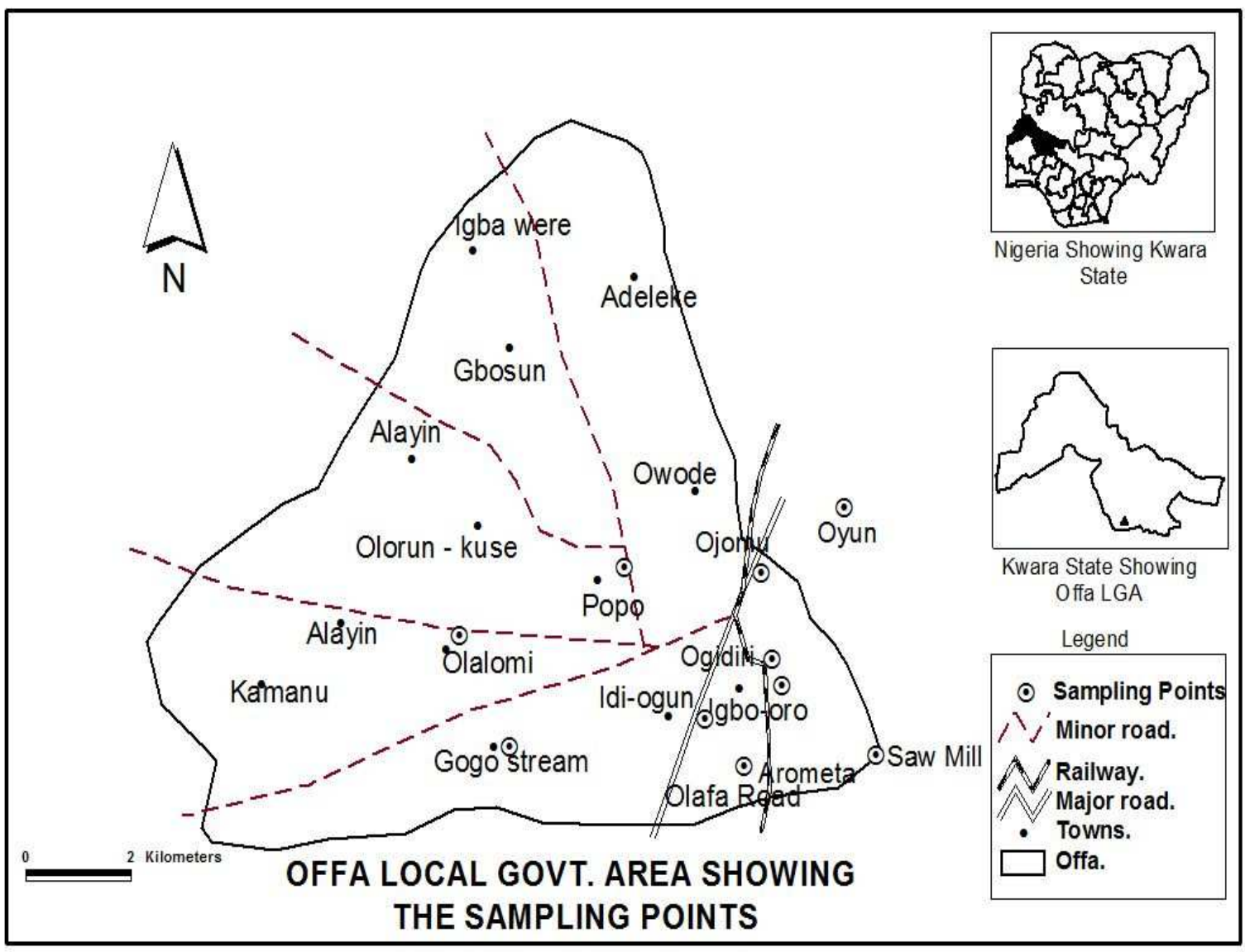

Fig. 1: Location of samples analysis for trace element

\section{Sampling of Stream and Tap water}

For stream water, grab samples were collected from top, bottom and the middle of the stream, along the direction of flow thrice daily at the interval of 3 hours. These were mixed to obtain composite samples and collected in a five litres polythene plastic container. For tap water, samples were collected thrice daily at an interval of an hour, mixed together to obtain composite samples and collected in a 5 litres polythene container (Soylak et al 2002).

\section{Sampling of Sachet water}

Sachet water were purchased and filled into a 5litres sample container. All sample bottles and caps were rinsed three times with water to be sampled during sampling (Akoto and Adiyiah, 2007). 


\section{Elemental Analysis of Water Sample}

Each of the 5.0 liters samples was evaporated to dryness using Pyrex beaker and hot plate. The residues were digested with $50 \mathrm{~cm}^{3}$ of $0.25 \mathrm{moldm}^{-3}$ nitric acid and transferred into $120 \mathrm{~cm}^{3}$ plastic container for Atomic Absorption Spectrophotometer (AAS) analysis. Metals concentrations were extrapolated from the standard calibration curve (Uduma 2008, Jimoh and Aminu 2011).

\section{Statistical Analysis}

All data generated were analysed statistically by calculating mean, standard deviation and coefficient of variation. The method used was described by Steel and Torne (1960).

\section{RESULTS AND DISCUSSION}

Investigations of the quality of drinking water samples have been continuously performed by researchers around the world (Bakraji and Karajo, 1999; Kot et al., 2000; Zereen et al., 2000; Jimoh and Aminu 2011).

Mineral and trace minerals are both essential to human health and maintaining adequate levels and balance in every tissue, fluid, cell and organ in the body may be the key considerations. If the body requires more than $100 \mathrm{mg}$ of a mineral each day, the substance is labeled a mineral. If the body requires less than this, it is labeled a trace mineral. Pure water does not exist in nature. The contamination of water is directly related to the degree of contamination of our environment. Rain water collects impurities while passing through the air. Streams and rivers collect impurities from surface run off and through the discharge of sewage and industrial effluents. These are carried to the rivers, lakes or reservoirs that supply our drinking water (Skeat 1969).

Medical geology is a subfield of geology that studies the effects of chemical in the environment, especially trace elements, on the health of humans and animals. The ultimate source of the body trace elements is generally rocks. The concentration of trace elements in rocks is varying by rock type. Sometimes they become concentrated in soil, water or in air taken up by plants and ingested by humans or animals (Dara 2006).

The concentration of chromium in the samples analysed is shown in

Table 1. Minimum concentration of $0.01 \mathrm{mgL}^{-1}$ was observed in sample (J) and maximum concentrations of $0.27 \mathrm{mgL}^{-1}$ were observed in samples ( $\mathrm{W}$ and $\mathrm{X}$ ). Twenty one (21) samples have concentrations above the recommended WHO threshold limit of $0.05 \mathrm{mgL}^{-1}$ while the remaining four samples (4) have concentrations within the WHO (2004) threshold limit.

The range of chromium concentrations in this study is lower than $0.06 \mathrm{mgL}^{-1}-2.65 \mathrm{mgL}^{-1}$ obtained by Abolude et al., (2009). High concentrations of chromium in the water samples may be attributed to anthropogenic activities (Dara, 2006).
Chromium is used in the metabolism and storage of fats, proteins and carbohydrates by the body. Chromium occurs in the environment primarily in two valence states, trivalent chromium (III) and hexavalent chromium (VI). Chromium (III) is much less toxic than chromium (VI) (ATSDR 1998). The body has several systems for reducing chromium (VI) to chromium (III). This chromium (VI) detoxication leads to increased levels of chromium (III) (ATSDR 1998). Cobalt concentrations in the samples analysed is shown in Table 1 . The concentrations range from $0.000 \mathrm{mgL}^{-1}-0.018 \mathrm{mgL}^{-1}$. All the samples analysed have concentrations within the WHO (2004) threshold limit of $0.05 \mathrm{mgL}^{-1}$ except in sample $D$ which is not detected. Low concentrations of cobalt in the samples may be attributed to the domestic and agricultural effluents (Abolude et al., 2009). The metabolism of vitamin $B_{12}$ and the daily ingestion of cobalt containing foodstuffs provide the most significant source of cobalt (e.g. background level) in the human body. Background levels of cobalt are not known to be associated with adverse health effects in humans (Barceloux, 1999).

The levels of Co found in surface waters of the Pacific and Atlantic oceans are very low, averaging below $30 \mathrm{mg} / \mathrm{l}$ of sea water (i.e. $0.00003 \mathrm{~g}$ per litre) (Neal et al., 1996). Variations in copper concentrations in the samples are shown inTable 1. The Concentration ranged between $0.001 \mathrm{mgL}^{-1}$ and $0.023 \mathrm{mgL}^{-1}$. Copper is an essential nutrient, but at high dose, it has been shown to cause stomach and intestinal distress, liver and kidney damage and anemia (EPA, 2003). Copper is intimately involved with a number of other vitamins and minerals. Copper and zinc levels are very closely interrelated. If an excess of one is found in the diet, the other will likely be deficient.

Iron concentrations in the samples are shown in Table 1. Minimum concentration of $0.025 \mathrm{mgL}^{-1}$ was found in sample $(L)$ and a maximum concentration of $0.13 \mathrm{mgL}^{-1}$ was observed in sample (P). All the samples analysed have concentrations within the WHO (2004) limit of $3.0 \mathrm{mgL}^{-1}$.

The form in which iron is taken has a significant effect on its bioavailability and haem - form is much better absorbed and utilized by the body.

Magnesium concentrations in the analysed samples are shown in Table 1 . The concentrations ranged between $0.007 \mathrm{mgL}^{-1}-0.082 \mathrm{mgL}^{-1}$. All the samples analysed have concentrations within the WHO (2004) threshold limit of $20.0 \mathrm{mgL}^{-1}$. High dose of magnesium in food supplements may cause nerve problems and depressions (Grandjean and Campbell, 2004).

Table 1 shows the concentrations of manganese in the samples. The concentration ranged between $0.000 \mathrm{mgL}^{-1}$ and $0.009 \mathrm{mgL}^{-1}$. All the samples analysed have concentrations within the WHO (2004) threshold limit of $0.40 \mathrm{mgL}^{-1}$. The highest concentration obtained in this study was lower than $0.09 \mathrm{mgL}^{-1}-2.83 \mathrm{mgL}^{-1}$ reported by Indu et al. (2010). 
Bajopas Volume 4 Number 2 December, 2011

Table 1: Concentration of the metals in water samples analysed ( $\mathrm{mg} / \mathrm{L})$.

\begin{tabular}{|c|c|c|c|c|c|c|}
\hline $\begin{array}{l}\text { Sampling } \\
\text { Code }\end{array}$ & $\mathrm{Cr}$ & Co & $\mathrm{Cu}$ & $\mathbf{F e}$ & Mg & Mn \\
\hline A & 0.03 & 0.008 & 0.001 & 0.045 & 0.014 & 0.009 \\
\hline$B$ & 0.05 & 0.006 & 0.001 & 0.065 & 0.017 & 0.007 \\
\hline C & 0.03 & 0.002 & 0.005 & 0.065 & 0.044 & 0.002 \\
\hline D & 0.04 & 0.000 & 0.004 & 0.06 & 0.007 & 0.004 \\
\hline$E$ & 0.06 & 0.002 & 0.007 & 0.05 & 0.009 & 0.000 \\
\hline $\mathrm{F}$ & 0.06 & 0.004 & 0.005 & 0.07 & 0.074 & 0.009 \\
\hline $\mathrm{G}$ & 0.07 & 0.004 & 0.007 & 0.08 & 0.03 & 0.005 \\
\hline $\mathrm{H}$ & 0.07 & 0.006 & 0.004 & 0.07 & 0.082 & 0.003 \\
\hline I & 0.03 & 0.004 & 0.004 & 0.075 & 0.034 & 0.006 \\
\hline J & 0.01 & 0.012 & 0.004 & 0.055 & 0.036 & 0.004 \\
\hline $\mathrm{K}$ & 0.10 & 0.008 & 0.004 & 0.04 & 0.014 & 0.005 \\
\hline $\mathrm{L}$ & 0.11 & 0.006 & 0.004 & 0.025 & 0.015 & 0.003 \\
\hline $\bar{M}$ & 0.08 & 0.018 & 0.013 & 0.055 & 0.02 & 0.003 \\
\hline $\mathrm{N}$ & 0.13 & 0.014 & 0.019 & 0.085 & 0.007 & 0.009 \\
\hline 0 & 0.10 & 0.002 & 0.015 & 0.035 & 0.029 & 0.004 \\
\hline$P$ & 0.11 & 0.006 & 0.009 & 0.13 & 0.036 & 0.002 \\
\hline $\mathrm{Q}$ & 0.12 & 0.002 & 0.01 & 0.08 & 0.026 & 0.004 \\
\hline $\mathrm{R}$ & 0.08 & 0.004 & 0.013 & 0.06 & 0.025 & 0.003 \\
\hline$S$ & 0.12 & 0.01 & 0.004 & 0.05 & 0.032 & 0.005 \\
\hline $\mathrm{T}$ & 0.18 & 0.016 & 0.01 & 0.085 & 0.066 & 0.004 \\
\hline$U$ & 0.21 & 0.012 & 0.023 & 0.075 & 0.053 & 0.003 \\
\hline V & 0.18 & 0.004 & 0.011 & 0.09 & 0.03 & 0.003 \\
\hline W & 0.27 & 0.006 & 0.007 & 0.035 & 0.036 & 0.004 \\
\hline$X$ & 0.27 & 0.008 & 0.004 & 0.1 & 0.046 & 0.005 \\
\hline$Y$ & 0.24 & 0.012 & 0.008 & 0.09 & 0.05 & 0.008 \\
\hline
\end{tabular}


Table 2: Mean concentration of trace metals $\left(\mathrm{mgL}^{-1}\right)$ with the corresponding standard deviations and coefficient of variations of the various water samples.

\begin{tabular}{|c|c|c|c|c|c|c|c|c|c|c|c|c|c|c|c|c|c|c|}
\hline Samples & Mean & $\begin{array}{l}\text { Cr } \\
\text { SD }\end{array}$ & CV & $\begin{array}{l}\text { Co } \\
\text { Mean }\end{array}$ & SD & CV & $\begin{array}{l}\text { Cu } \\
\text { Mean }\end{array}$ & SD & CV & $\begin{array}{l}\text { Fe } \\
\text { Mean }\end{array}$ & SD & CV & $\begin{array}{l}\text { Mg } \\
\text { Mean }\end{array}$ & SD & CV & $\begin{array}{l}\text { Mn } \\
\text { Mean }\end{array}$ & SD & CV \\
\hline Borehole & 0.049 & 0.007 & 0.143 & 0.004 & 0.003 & 0.750 & 0.004 & 0.002 & 0.5 & 0.062 & 0.011 & 0.177 & 0.028 & 0.022 & 0.786 & 0.005 & 0.003 & 0.6 \\
\hline Well & 0.194 & 0.064 & 0.330 & 0.009 & 0.004 & 0.444 & 0.010 & 0.006 & 0.6 & 0.073 & 0.020 & 0.274 & 0.042 & 0.013 & 0.31 & 0.004 & 0.002 & 0.5 \\
\hline Sachet & 0.064 & 0.040 & 0.625 & 0.018 & 0.021 & 1.167 & 0.005 & 0.001 & 0.2 & 0.053 & 0.019 & 0.358 & 0.036 & 0.011 & 0.31 & 0.004 & 0.001 & 0.25 \\
\hline Tap & 0.110 & 0.008 & 0.073 & 0.003 & 0.002 & 0.667 & 0.011 & 0.003 & 0.273 & 0.080 & 0.034 & 0.425 & 0.003 & 0.004 & 1.333 & 0.003 & 0.001 & 0.333 \\
\hline Stream & 0.110 & 0.025 & 0.227 & 0.016 & 0.002 & 0.125 & 0.016 & 0.003 & 0.187 & 0.070 & 0.015 & 0.214 & 0.015 & 0.005 & 0.333 & 0.006 & 0.030 & 5.0 \\
\hline $\begin{array}{l}\text { WHO (2004) maximum } \\
\text { permissible level }\end{array}$ & 0.05 & & & 0.05 & & & 2.0 & & & 3.0 & & & 20.0 & & & 0.4 & & \\
\hline
\end{tabular}

\section{CONCLUSION}

The goal of this study was to gather information about the quality of wate being distributed to selected Offa communities in Kwara State. Since the communities studied are farm communities our results are not surprising.

In conclusion, the concentrations of the investigated metal ions in the drinking water samples from Offa metropolis were found to be below the guide

\section{REFERENCES}

Abolude, D. S., Davies, O. A and Chia, A. M. (2009): Distribution and Concentration of Trace Elements in Kubanni Reservoir in Northern Nigeria. Journal of Environmental and Earth Science 1(2): 39-44.

Akoto, O. and Adiyiah, J. (2007): Chemical Analysis of Drinking Water from some Communities in the Brong Ahafo Region. Int. J. Environ. SCl Tech., 4(2), $211-214$

Anawara, H. M., Akaib, J., Mostofac, K. M. G., Safiullahd, S.and Tareqd, S. M. (2002): Arsenic Poisoning in Ground Water Health Risk and Geochemical Sources in Bangladesh. Environ. Int., 27, 587 - 604. lines for drinking water given by the world health organization (WHO) except chromium with twenty one samples above WHO threshold limit and four samples were within the limit. The data collected in this study and from future studies will be disseminated to the community leaders.

Anderson, M. B., Pedigo, N. G., Katz, R. P. and George, W. J. (1992):

Histopathology of Testes from Mice Chronically Treated with Cobalt. Repro. Toxicol. 6: $41-50$.

Aswathanarayana, U. (1994): Trace Substances Environment and Health Science Reviews, London 1: 22 - 232.

ATSDR (1998): Toxicology Profile for Chromium, U.S. Public Health Sevices, U.S Department of Health and Human Services, Atlanta GA. Agency for Toxic Substances and Disease Registry pp. $285-300$. 
Bakraji, E. H. and Karajo, J. (1999): Determination of Heavy Metals in Damascus Drinking Water using Total Reflection X - ray Fluorescence. Water Quality Research J. Canada 34: 305 310.

Bamishaiye, E. I., Ogbonna, O; Jimoh, W. L. and Awagu, E. F. (2011): Determination of some trace elements in water samples within Kano metropolis. Journal of Advances in Applied Science Research, 2(2): $62-68$.

Barceloux, D. G. (1999): Cobalt. Clinical Toxicology 37(2): $201-216$

Dara, S. S., (2006): Environmental Chemistry and Pollution control. $8^{\text {th }}$ ed. S. Chand and Company Ltd. Ram Nagar, New Delhi. Pp. $177-215$.

Environmental Protection Agency (EPA), (2003): Chemical Contaminants in Drinking Water. Technical Fact Sheet on Microbes EPA 816 $03-016$.

Ferrarello, C. N., Bayon, M. M., Alonso, J.I.G and Sanz - Medel, A. (2001): Comparison of Metal Pre - Concentration on Immobilized Kelex - 100 and Quadruple Inductively Coupled Plasma Mass Spectrometric Detection with Direct Double Focusing Inductively Coupled Plasma Mass Spectrometric Measurements for Ultra Trace Multi Element Determination in Sea Water. Anal. Clim. Acta, 429: 227 - 241.

Grandjean, A. C. and Campbell, S. M. (2004): Hydration: Fluids for Life. A Monograph by the North American Branch of the International Life Sciences Institute. Washington, DC Pp. $30-31$,

Indu. V. N, Kailash.S, Arumuugam. M. Grangadhar. K and Carlson.D. (2010): Trace Metal Quality of Meenachil River at Kottayam, Kerala (India) by Principal Component Analysis. Applied Science. Journa/9(10): 1100 - 1107.

Jimoh, W .L. O and Aminu, D. O. (2011): Study of Trace Elements Quality in Drinking Water Supply in Ifelodun Local Government Area, Ikirun, Osun State, Nigeria. Biol. and Environ. Sci. Journ. For the Tropics 8: $99-103$.

Kot, B., Baranowski, R., and Tybak, A. (2000): Analysis of Mine Waters using X-ray Fluorescence Spectrometry. Polish Journal of Environmental Studies, 9: 429 - 433.

Mustapha, M. K. (2008): Assessment of the Water Quality of Oyun Reservoir Offa, Nigeria Using Selected Physico Chemical Parameters. Turk. J. Fish Aquat. Sci. 8: 309 - 319.

Neal, C., Smith, C. J., Jefferey H. A., Jervie, H. P. and Robson, A. J. (1996): Trace Element Concentrations in the Major Rivers Entering the Humber Estuary. N.E. England Journal of Hydrology 182: $37-64$.
Pedigo, N. G., George, W. J. and Anderson M. B (1988): Effects of Acute and Chronic Exposure to Cobalt on Male Reproduction in Mice. Repro. Toxicol. 2: $45-53$.

Quinaia, S. P., DaSilva, J. B. B., Rosellemberg, M. C. E. and Curtius, A. J. (2001): Preconcentration of Lead Complexed with O, O - diethyl dithiophosphate by Column Solid - Phase Extraction using Different Sorbents in a Flow Injection System Coupled to a Flame Atomic Absorption Spectometer. Talanta, 54:687 698.

Salonia, J. A., Wuilloud, R. G., Gasquez, J. A., Olsina, R. A and Martinez, L. D (1999): Determination of Lead in Tap Water by ICP AES with Flow - Injection on - Line Adsorption Preconcentration using a Knotted Reactor and Ultrasonic Nebulization. J. Anal. At. Spectr. 14: $1239-1248$.

Samuel M., Taddese, W., Richard, D. and Luc, M. (2004): Simultaneous Determination of Trace Elements in Tinishu Akaki River Water Sample, Ethiopia by ICP - MS. Canad. Journ. of Anal. Sci. and Spectroscopy. 49: 376 384.

Singh, S. and Mosley, L. M. (2003): Trace Metals Levels in Drinking Water on Viti Lerv. Fiji Islands. Pac. J. Nat. Sci. 21:31 - 34.

Skeat, W. O. (1969): Manual of British Water Engineering Practice. Vol. b: Water Quality and Treatment. The Institution of Water Engineers London. England pp $79-91$.

Soylak, M., Aydin, F. A, Saracoglu, S., Elci, L. and Dogan, M. (2002): Chemical Analysis of Drinking Water Samples from Yozgat, Turkey.

Polish Journal of Environ. Studies 11: 151 156.

Steel, R. G. D. and Torne, J. A. (1960): Principles and Procedures for Statistics McGraw Hill, London pp. $45-51$.

Uduma, A. U. (2008): Physico - Chemical Analysis of the Quality of Sachet Water in Kano Metropolis M.Sc. Dissertation, Department of Pure and Industrial Chemistry Bayero University Kano. Pp 30.

World Health Organization (2004): Guidelines for Drinking Water Quality WHO Geneva.Switzerland pp 21-86.

Wikipedia(2010):Zamfara State Lead Poisoning Epidemic

www.reuters.com/article/idUSTRE6534JE201 04 Retrieved 4 June 2010.

Zereen, F., Islam, F., Habib, M. A., Begun, D. A. and Zaman, M. S. (2000); Inorganic Pollutants in The Padma River, Bangladesh. Environ. Geology 39: 1059 - 1065. 